\title{
APPLICATION OF THE VIENNA CLASSIFICATION FOR CROHN'S DISEASE TO A SINGLE CENTER FROM BRAZIL
}

\author{
Genoile Oliveira SANTANA ${ }^{1,3}$, Lorena Rocha SOUZA ${ }^{2}$, Matheus AZEVEDO² , Ana Carolina SÁ ${ }^{2}$, \\ Clara Maia BASTOS ${ }^{2}$ and André Castro LYRA ${ }^{1,2,3}$
}

\begin{abstract}
Background - Crohn's disease is a chronic inflammatory disorder with diversity on its clinical presentation that may be observed from the varying age of onset of symptoms to the site of occurrence of the illness. There is a need for a replicable and uniform description of the disease allowing a comparison between distinct study populations. The 1998 Vienna classification characterizes patients according to three clinical aspects: age at diagnosis, location and disease behavior. Aim - To describe Crohn's disease in patients from a reference center of Salvador, BA, Brazil according to the Vienna classification. Methods - Between January and October of 2005, patients $(n=47)$ having at least one endoscopic and radiological examination of the intestine participated in this study. Results - Most of the participants had the diagnosis of the disease when they were younger than 40 years old $(70.2 \%)$ while an ileocolic location (38.3\%) and the penetrating form (46.8\%) were the most prevalent clinical presentation. The restricted location of the ileum (L1) was more frequent in nonstricturing, nonpenetrating disease (B1) while the ileocolic disease (L3) was more associated with the penetrating behavior (B3). Conclusion - In this study, differently from the first description of the Vienna classification, the large number of patients presenting a complicated stage of the disease can be attributed to the fact that it was carried out at a reference center, where many patients present with the disease at an advanced stage.
\end{abstract}

HEADINGS - Crohn disease, classification.

\section{INTRODUCTION}

Crohn's disease is a chronic inflammatory disorder of unknown etiology and with significant clinical variability. Therefore, the utilization of a uniform and reproducible description of the disease is necessary in order to make it possible the comparison between distinct study samples and the evaluation of the genetic influence on the presentation of the disease. In 1998 the Vienna Classification emerged with the goal to standardize Crohn's disease classification according to clinical features and reproducible criteria $^{(5)}$. The aspects that were considered relevant are age at diagnosis, location and clinical behavior of the disease.

Age at diagnosis was defined as the one at the moment the diagnosis was definitely established through radiological, endoscopic or surgical evaluation. There are two possibilities: below 40 years (A1) and equal to or above 40 years (A2). The location was defined as the largest anatomic extension of the disease in any previous period of the first surgery. There are four possibilities: terminal ileum (L1, limited disease at the inferior third of the small intestine with or without involvement of the cecum), colon (L2, any location between the cecum and the rectum, without involvement of the upper digestive tract), ileocolic (L3, terminal ileum disease and any place between the ascending colon and the rectum) and upper gastrointestinal tract (L4, any location upper to the terminal ileum, except mouth) ${ }^{(5)}$. The clinical behavior is classified as stricturing (B2), penetranting (B3), and nonstricturing nonpenetrating (B1). Stricturing disease was defined by the occurrence of constant lumen stricture showed by radiological evaluation, endoscopy or surgery without evidence of penetration. However, penetrating disease was defined by the occurrence of abdominal or perianal fistulas and inflammatory masses, and/or abscess in any period of the evolution of the disease. Finally, nonstricturing and nonpenetrating disease was defined as inflammation with no evidence of stricture or penetration. Gender, patient's age, ethnicity, Jewish ascendance, family history and extraintestinal involvement are additional information described separately ${ }^{(5)}$.

Several studies have used the Vienna Classification to describe the characteristics of their patients. VELOSO

${ }^{1}$ Gastrohepatology Unit, Federal University of Bahia, Brazil; '2Department of Medicine, Federal University of Bahia, Brazil; ${ }^{3}$ Gastrohepatology Unit Hospital San Rafael, Bahia, Brazil

Correspondence : Dr. Genoile Oliveira Santana - Av. Santos Dumont, km 5 - Condomínio Parque Encontro das Águas, Lote G31 - $42700-000$ - Lauro de Freitas, BA Brazil. E-mail: genoile@uol.com.br 
et al. ${ }^{(14)}$ detected differences in prognosis between subgroups of patients with Crohn's disease classified according to criteria of Vienna. LOUIS et al. ${ }^{(9)}$ found changes in the clinical behavior during the course of the disease. DORN et al. ${ }^{(2)}$ noticed differences between familiar and occasional cases as for the clinical behavior of the Crohn's disease. To our knowledge there are no studies using the Vienna Classification in Brazil.

Therefore, the goal of the present study was to describe the characteristics of Crohn's disease patients in one reference center in Salvador, BA, Brazil according to the criteria of Vienna.

\section{METHODS}

The study group comprised patients with Crohn's disease who were being followed at the Gastroenterology Outpatient Service from the University Hospital Prof. Edgard Santos. This is a reference center for inflammatory bowel disease. They were enrolled from January 2005 to October 2005. Informed written consent was obtained from all subjects and the study protocol conformed to the ethical guidelines of the 1975 Declaration of Helsinki. It was approved by the Hospital Ethics Committee. Eligible patients had all the following inclusion criteria:

- adult with well established diagnosis of the Crohn's disease under regular follow-up;

- patient with complete diagnostic evaluation (at least an endoscopic study of the large bowel and a radiological study of the small intestine);

Each patient answered a specific questionnaire. The medical chart was evaluated for additional data. The questionnaire had information about:

- demographics (sex, age, race, Jewish ascendancy);

- clinical aspects of Crohn's disease (date of first symptoms and of diagnosis, type of presentation and family history);

- description of colonoscopy and radiological findings.

Patients were characterized according with the Vienna Classification of 1998. Race was described as white, mulatto and black by subjective evaluation based on established criteria by KRIEGER et al. ${ }^{(8)}$ and modified by AZEVÊDO ${ }^{(1)}$.

All patients with Crohn's disease evaluated at the study period were included in the study. The frequencies of the discreet variables were analyzed and continuous variable were described as mean \pm standard-deviation. All statistical analyses were conducted by the statistical software package SPSS for windows.

\section{RESULTS}

During the study period 47 patients fulfilled the inclusion criteria. The mean age among those analyzed was 38.5 years old. The mean time after the diagnosis of Crohn's disease was 64.6 months. Almost all subjects (98\%) were from the urban area (Table 1).

With respect to age at diagnosis, $70.2 \%$ were classified as A1 (below 40 years) and $29.8 \%$ as A2 (equal to or above 40 years). As for the disease location $19.1 \%$ had classification
TABLE 1. Demographics and clinical characteristics of patients with Crohn's disease in reference service in Salvador, Bahia-Brazil,2005

\begin{tabular}{lc}
\hline Variable & $\begin{array}{c}\text { Study population } \\
(\mathbf{n}=47)\end{array}$ \\
\hline $\begin{array}{l}\text { Age in years } \\
\text { Mean } \pm \text { SD* }\end{array}$ & $38.5 \pm 14.3$ \\
$\begin{array}{l}\text { Mean time of diagnosis in months } \\
\text { mean } \pm \text { SD* }\end{array}$ & $64.6 \pm 69.8$ \\
Area of origin $n(\%)$ & \\
Urban & $46(97.9)$ \\
Rural & $1(2.1)$ \\
\hline *SD: standard deviation &
\end{tabular}

L1 (terminal ileum), 21.3\% were classified as L2 (colon), 38.3\% as L3 (ileocolic) and $21.3 \%$ as L4 (upper gastrointestinal tract). According to the disease behavior, $46.8 \%$ were classified as B3 (penetrating), $12.8 \%$ as B2 (stricturing) and $40.4 \%$ as B1 (nonstricturing and nonpenetrating) (Table 2).

TABLE 2. Application of the Vienna classification in patients with Crohn's disease in a reference service in Salvador, BA, Brazil, 2005

\begin{tabular}{lc}
\hline Variable & $\begin{array}{c}\text { Total number of patients }=47 \\
\mathbf{n}(\%)\end{array}$ \\
\hline Age at diagnosis & \\
A1 (<40 years) & $33(70.2)$ \\
A2 ( $\geq 40$ years) & $14(29.8)$ \\
Location & \\
L1 (terminal ileum) & $9(19.1)$ \\
L2 (colon) & $10(21.3)$ \\
L3 (ileocolic) & $18(38.3)$ \\
L4 (upper gastrintestinal tract) & $10(21.3)$ \\
& \\
Behaviour & \\
B1 (nonstricturing nonpenetrating) & $19(40.4)$ \\
B2 (stricturing) & $6(12.8)$ \\
B3 (penetrating) & $22(46.8)$ \\
\hline
\end{tabular}

The female gender was predominant $(70.2 \%) ; 63.8 \%$ of patients were classified as mulatto; $27.7 \%$ as white and $8.5 \%$ as blacks; 3 patients had Jewish ascendancy and just one had family history for Crohn's disease (Table 3).

TABLE 3. Application of the Vienna classification in patients with Crohn's disease in a reference service in Salvador, BA, Brazil, 2005

\begin{tabular}{lc}
\hline Variable & $\begin{array}{c}\text { Total number of patients }=47 \\
\mathbf{n}(\%)\end{array}$ \\
\hline $\begin{array}{l}\text { Gender } \\
\text { Female } \\
\text { Male }\end{array}$ & $33(70.2)$ \\
Race & $14(29.8)$ \\
$\quad$ White & \\
Black & $13(27.7)$ \\
Mulatto & $4(8.5)$ \\
Jewish ascendancy & $30(63.8)$ \\
Familiar history & $3(6.4)$ \\
Extraintestinal manifestations & $1(2.1)$ \\
\hline
\end{tabular}


The results showed a predominance of nonstricturing nonpenetrating disease (B1) in terminal ileum (L1) and penetrating form (B3) in ileocolic disease (L3), corresponding, respectively, to $14.9 \%$ and $19.1 \%$ of the cases (Table 4 ). When all patients were divided into the 24 subgroups of Vienna Classification, there was a higher frequency of patients with the age below 40 years at diagnosis (A1) and ileocolic (L3) and penetrating behavior (B3), corresponding to $14.9 \%$ of the cases (Table 5 ). In five subgroups of Vienna Classification no patients could be allocated (A1L1B2, A1L2B2, A2L1B2, A2L3B2 and A2LB2B3). It was detected a higher frequency of penetrating disease $(66.7 \%)$ in the patients who had been diagnosed for 10 years or more while the nonstricturing nonpenetrating $(44.7 \%)$ was more frequent in patients who had been diagnosed for less than 10 years (Table 6).

TABLE 4. Crohn's disease behavior according to location in the study population, 2005

\begin{tabular}{lcccc}
\hline & \multicolumn{4}{c}{ Total number of patients $=47$} \\
\cline { 2 - 5 } Location & $\mathbf{B} 1$ & $\mathbf{B} 2$ & $\mathbf{B} 3$ & Total \\
& $\begin{array}{c}\text { (NS NP*) } \\
\mathbf{n}(\%)\end{array}$ & $\begin{array}{c}\text { (Stricturing) } \\
\mathbf{n}(\%)\end{array}$ & $\begin{array}{c}\text { (Penetrating) } \\
\mathbf{n}(\%)\end{array}$ & $\mathbf{n}(\%)$ \\
\hline L1 (terminal ileum) & $7(14.9)$ & $0(0)$ & $2(4.2)$ & $9(19.1)$ \\
L2 (colon) & $4(8.5)$ & $1(2.1)$ & $15(10.6)$ & $10(21.3)$ \\
L3 (ileocolic) & $6(12.8)$ & $3(6.4)$ & $9(19.1)$ & $18(38.3)$ \\
L4 (UGT $* *)$ & $2(4.2)$ & $2(4.2)$ & $6(12.8)$ & $10(21.3)$ \\
Total & $19(40.4)$ & $6(12.8)$ & $22(46.8)$ & $47(100.0)$ \\
\hline
\end{tabular}

${ }^{*}$ NS NP: nonstricturing nonpenetrating

**UGT: upper gastrointestinal tract

TABLE 5. Distribution of the patients from the study population in all 24 subgroups of the Vienna classification in Salvador, BA, Brazil, 2005

\begin{tabular}{lccccccc}
\hline \multicolumn{7}{c}{ A1 } & \multicolumn{5}{c}{ A2 } \\
\hline & B1 n(\%) & B2 n(\%) & B3 n(\%) & B1 n(\%) & B2 n(\%) & B3 n (\%) & Total n (\%) \\
L1 & $4(8.5)$ & - & $1(2.1)$ & $3(6.4)$ & - & $1(2.1)$ & $9(19.1)$ \\
L2 & $2(4.2)$ & - & $5(10.6)$ & $2(4.2)$ & $1(2.1)$ & - & $10(21.2)$ \\
L3 & $4(8.5)$ & $3(6.4)$ & $7(14.9)$ & $1(2.1)$ & - & $2(4.2)$ & $17(36.2)$ \\
L4 & $1(2.1)$ & $1(2.1)$ & $5(10.6)$ & $2(4.2)$ & $1(2.1)$ & $1(2.1)$ & $11(23.4)$ \\
Total & $11(23.4)$ & $4(8.5)$ & $18(38.3)$ & $8(17.0)$ & $2(4.2)$ & $4(8.5)$ & $47(100.0)^{*}$ \\
\hline
\end{tabular}

*Total number of patients $=47$

TABLE 6. Crohn's disease in patients with diagnosis for less than 10 years and from 10 years in a reference service in Salvador, BA, Brazil, 2005

\begin{tabular}{lcc}
\hline Behavior & $\begin{array}{c}\text { Diagnosis for less than } \\
10 \text { years } \\
\mathbf{n}(\%)\end{array}$ & $\begin{array}{c}\text { Diagnosis from } \\
10 \text { years } \\
\mathbf{n}(\%)\end{array}$ \\
\hline B1 (nonstricturing nonpenetrating) & $17(44.7)$ & $2(22.2)$ \\
B2 (stricturing) & $5(13,2)$ & $1(11.1)$ \\
B3 (penetrating) & $16(42.1)$ & $6(66.7)$ \\
Total & $38(100.0)$ & $9(100.0)$ \\
\hline
\end{tabular}

\section{DISCUSSION}

Crohn's disease is an illness with heterogeneous presentation and therefore it is important to provide a systematized and uniform description of the disease. This issue has great relevance when studies intend to evaluate genetic and environmental aspects associated with the disease or to include specific subgroups of patients for clinical trials. Early age at diagnosis is a variable that may indicate a major genetic predisposition, or perhaps an earlier or greater exposure to major determinant environmental factors. In agreement with the original study ${ }^{(5)}$ the majority of our patients were younger than 40 years old reinforcing that this is a disease of the youth.

The study population showed a higher frequency of the penetrating form of the disease with almost half of the patients been classified as B3. Another study from a tertiary center also showed a high prevalence of the penetrating form of the disease $(38.8 \%)$ which required immunosuppressive therapy ${ }^{(15)}$. The high frequency of patients with complicated disease can be attributed to the fact that our patients were from a tertiary center to where they are referred because many of them already have advanced disease.

During the evolution of the illness it is possible to detect an increase or a decrease of the extension of the disease mostly in the same anatomic location without changing the classification using the Vienna criteria. Location of Crohn's disease as defined by the Vienna classification is a relatively stable phenotype. At the present study, most patients had ileocolic disease (38.8\%), in contrast to the original publication of Vienna where the colonic location was more prevalent with $35.8 \%$ of the patients been classified as L2 ${ }^{(5)}$. Another study from a tertiary center also showed a higher frequency of ileocolic location $(37.0 \%)^{(15)}$, reinforcing these findings and from others investigations ${ }^{(6,9)}$.

Among the additional information collected for the classification the low frequency of patients with a family history of Crohn's disease may be explained by the difficulty in analyzing this variable since many patients do not have this information about their family members or perhaps the disease is misdiagnosed. In spite of the high number of Afro-descendant patients, the distribution of the different racial groups ( $71 \%$ of mulattos, $16 \%$ of whites and $13 \%$ of blacks) was similar to the distribution of the population of the State of Bahia, Brazil ${ }^{(1)}$. Perhaps the disease among us does not show any difference in its frequency among the racial groups.

There are reports about the association of the disease restricted to the ileum (L1) to the stricturing disease (B2), however in our study we did not detect this association in any of the patients ${ }^{(6)}$. This might be explained by the small number of cases or by the fact that our service has a clinical and not a surgical profile. Usually patients with the diagnosis of intestinal occlusion are referred to a surgical team. There was an increased frequency of patients with the disease restricted to the ileum with the behavior of nonstricturing nonpenetrating disease. This was the second major group found isolated.

Of note, there was a high frequency of the penetrating form in patients with ileocolic disease. In a previous study from our group we evaluated patients with active fistulizing Crohn's disease and we found a high frequency $(50 \%)$ of ileocolic disease among them ${ }^{(10)}$. This finding has been described by other authors ${ }^{(3,6)}$.

It is still believed that involvement of the small intestine and upper gastrointestinal tract is more common in subjects diagnosed under the age of 20 years while the colonic disease is frequently diagnosed in patients over the age of 60 years ${ }^{(4)}$. In this study that included only adult patients we did not find differences on the disease location according to the age at diagnosis. The high 
frequency of involvement of the upper gastrointestinal tract is in agreement with the results found in a population-based study from Denmark which patients from a cohort without pediatric patients had more frequently upper gastrointestinal involvement (19\%) than others two cohorts with pediatric patients ${ }^{(7)}$. Further studies about the pathogenesis of upper gastrointestinal involvement in Crohn's disease may explain these observations.

In this study, after classifying the patients according to the 24 subgroups of the Vienna classification the most frequent subgroup found was of patients with age less than 40 years old at diagnosis (A1), ileocolic disease (L3) and penetrating behavior (B3). This finding is somewhat different from the one from GASCHE et al. ${ }^{(5)}$, in which the subgroup most frequently found was A1L2B1 ( $20.4 \%$ of the cases). The lack of the detection of five subgroups (A1L1B2, A1L2B2, A2L1B2, A2L3B2 and A2L2B3) may be due to the small number of patients of our study.

Were found an increased frequency of individuals with the penetrating form of the disease among those who had been diagnosed for 10 years and over when it is compared to subjects with less than 10 years from the diagnosis. It is well established that the presentation of Crohn's disease has a trend to progress from its original behavior during the patient follow up ${ }^{(9,12)}$. A study from Belgium ${ }^{(9)}$ showed that while the majority of the patients had a non complicated disease (B1) at diagnosis, only in a few the behavior of the disease remained stable after 25 years of follow-up and the majority of patients had changed their classification after 10 years of disease. The development of stricturing or penetrating disease probably represents a multifactorial phenomenon involving genetic and environmental factors including the type of therapy utilized. In order to analyze this data with more caution it should be taken into consideration the period of follow-up of the patients. Prospective studies could bring answers to many questions related to the characteristic of the disease according to the period of its evolution.

During the World Congress of Gastroenterology at September 2005 , in Montreal, it was proposed a new classification based on the Vienna classification. It was suggested to improve the details about the stratification of age at diagnosis, to associate involvement of upper gastrointestinal tract with terminal ileal disease, colonic or ileocolonic disease, and to describe perianal involvement in any of the behaviors of the disease ${ }^{(13)}$. If new classifications are developed they should be easy to apply for both clinical purposes as well as for scientific aims.

It is important to note that Vienna Classification has been recently validated ${ }^{(11)}$ and appears to be of easy application for both clinical and scientific purpose. Nevertheless the absence of prospective evaluation does not allow the characterization of the evolution of the patients. On the other hand, it is useful to identify the profile of patients in order to adopt better-direct health public policies and optimize investments in the field.

\section{ACKNOWLEDGEMENTS}

The authors are in debt with Prof. Luiz G. Costa Lyra, Prof. Jorge Carvalho Guedes and Prof. Maria Betania Toralles for their invaluable assistance in the development of this study.

Santana GO, Souza LR, Azevedo M, Sá AC, Bastos CM, Lyra AC. Aplicação da classificação de Viena para doença de Crohn em um centro no Brasil. Arq Gastroenterol. 2008;45(1):64-8.

RESUMO - Racional - A doença de Crohn é um distúrbio inflamatório crônico com apresentação clínica diversa, o que pode ser observado desde a variação da idade de início dos sintomas até o local de ocorrência da doença. Existe a necessidade de uma descrição uniforme e replicável da doença que permita comparação entre diferentes populações estudadas. A classificação de Viena de 1998 caracteriza os pacientes de acordo com três aspectos clínicos: idade do diagnóstico, localização e comportamento da doença. Objetivo - Descrever a doença de Crohn em pacientes de um centro de referência de Salvador, BA, de acordo com a classificação de Viena. Método - Entre janeiro e outubro de 2005, participaram deste estudo pacientes ( $\mathrm{n}=47)$ que tiveram pelo menos um exame endoscópico ou radiológico do intestino. Resultados - A maioria dos participantes teve o diagnóstico da doença com idade menor do que 40 anos (70.2\%), enquanto a localização íleo-colônica (38,3\%) e a forma penetrante (46,8\%) foram as apresentações clínicas mais prevalentes. A localização restrita ao íleo (L1) foi mais freqüente na doença não-estenosante não-penetrante (B1), enquanto a doença íleo-colônica (L3) foi mais associada com o comportamento penetrante (B3). Conclusão - Neste estudo, diferente da descrição inicial da classificação de Viena, o grande número de pacientes apresentando-se com fase complicada da doença pode ser atribuído ao fato de ter sido realizado em um centro de referência, onde muitos pacientes comparecem com a doença avançada.

DESCRITORES - Doença de Crohn, classificação. 


\section{REFERENCES}

1. Azevêdo ES. Subgroup studies of black admixture within a mixed population of Bahia, Brazil. Ann Hum Genet. 1980;44:55-60.

2. Dorn SD, Abad JF, Panagopoulos G, Korelitz BI. Clinical characteristics of familia versus sporadic Crohn's disease using the Vienna classification. Inflamm Bowel Dis. 2004;10:201-6.

3. Farmer RG, Hawk WA, Turnbull RB Jr. Clinical patterns in Crohn's disease: a statistical study of 615 cases. Gastroenterology. 1975;68:627-35.

4. Freeman HJ. Age-dependent phenotypic clinical expression of Crohn's disease. J Clin Gastroenterol. 2005;39:774-7.

5. Gasche C, Scholmerich J, Brynskov J, D'Haens G, Hanauer SB, Irvine EJ, Jewell DP, Rachmilewitz D, Sachar DB, Sandborn WJ, Sutherland LR. A simple classification of Crohn's disease: report of the Working Party for the World Congresses of Gastroenterology, Vienna 1998. Inflamm Bowel Dis. 2000;6:8-15.

6. Greenstein AJ, Lachman P, Sachar DB, Springhorn J, Heimann T, Janowitz HD, Aufses AH Jr. Perforating and non-perforating indications for repeated operations in Crohn's disease: evidence for two clinical forms. Gut. 1988;29:588-92.

7. Jess T, Riis L, Vind I, Winther KV, Borg S, Binder V, Langholz E, Thomsen O, Munkholm P. Changes in clinical characteristics, course, and prognosis of inflammatory bowel disease during the last 5 decades: a population-based study from Copenhagen, Denmark. Inflamm Bowel Dis. 2007;13:481-9.

8. Krieger H, Morton NE, Mi MP, Azevêdo E, Freire-Maia A, Yasuda N. Racial admixture in north-eastern Brazil. Ann Hum Genetic. 1965;29:113-25.

9. Louis E, Collard A, Oger AF, Degroote E, Aboul Nasr El Yafi FA, Belaiche J. Behaviour of Crohn's disease according to the Vienna classification: changing pattern over the course of the disease. Gut. 2001;49:777-82.
10. Mello ACN, Santana GO, Santos RR, Guedes JC, Lyra LJ. Perfil da doença de Crohn fistulizante em dois serviços universitários em Salvador-Bahia. Rev Bras Coloproct. 2005;25:241-8.

11. Riis L, Munkholm P, Binder V, Skovgaard LT, Langholz E. Intra- and interobserver variation in the use of the Vienna classification of Crohn's disease. Inflamm Bowel Dis. 2005;11:657-61.

12. Schwartz DA, Loftus EV Jr, Tremaine WJ, Panaccione R, Harmsen WS, Zinsmeister AR, Sandborn WJ. The natural history os fistulizing Crohn's disease in Olmsted Country, Minnesota. Gastroenterology. 2002;122:875-80.

13. Silverberg MS, Satsangi J, Ahmad T, Arnott ID, Bernstein CN, Brant SR, Caprilli R, Colombel JF, Gasche C, Geboes K, Jewell DP, Karban A, Loftus Junior EV, Peña AS, Riddell RH, Sachar DB, Schreiber S, Steinhart AH, Targan SR, Vermeire S, Warren BF. Toward an integrated clinical, molecular and serological classification of inflammatory bowel disease: report of a working party of the 2005 Montreal World Congress of Gastroenterology. Can J Gastroenterol. 2005;19 ( $\operatorname{suppl}$ A):5-36.

14. Veloso FT, Ferreira JT, Barros L, Almeida S. Clinical outcome of Crohn's disease: analysis according to the Vienna classification and clinical activity. Inflamm Bowel Dis. 2001;7:306-13

15. Zankel E, Rogler G, Andus T, Reng CM, Scholmerich J, Timmer A. Crohn's disease patient characteristics in a tertiary referral center: comparison with patients from a population-based cohort. Eur J Gastroenterol Hepatol. 2005;17:395-401.

Recebido em 5/6/2007. Aprovado em 29/8/2007. 